\title{
A NON-POLEMICAL READING OF 1 JOHN: SIN, CHRISTOLOGY AND THE LIMITS OF JOHANNINE CHRISTIANITY
}

Terry Griffith

\begin{abstract}
Summary
This paper offers a new paradigm for understanding the treatment of sin and Christology in 1 John that does not require gnosticising or docetic-like opponents to account for its contours. Both the ethical debate about sin (1 Jn. 1:6-2:11; 3:4$17 ; 4: 20 ; 5: 16-18)$ and the confessional statements about Jesus (1 Jn. 2:22; 4:2$3,15 ; 5: 1,5,6)$ can be explained without reference to what the group that has left the Johannine community (2:19) positively believes. The issues at stake focus on the messiahship of Jesus, and the need to reinforce the limits of the Johannine community, not only by right confession but also by right conduct. Failure to keep either part of the dual commandment to believe in Jesus and to love one another (3:23) amounts to apostasy and places oneself outside the boundaries of Johannine Christianity. Confirmation of this approach is found in John's Gospel.
\end{abstract}

\section{Introduction}

It is still a commonplace in Johannine scholarship that the interpretative landscape of 1 John is defined by the contours of nascent Gnosticism or Docetism. That is to say, it is assumed that $1 \mathrm{John}$ is a polemical document whose purpose is to rebut the heretical christological speculations and associated spurious ethical claims of a Johannine splinter group. Frequently, this panorama is seen to adumbrate certain second-century heresies. ${ }^{1}$ However, the evidence for such trajectories is surprisingly tenuous, and one cannot but feel that $1 \mathrm{John}$ is frequently interpreted in the light of later developments. This

${ }^{1}$ However, note the caution in the most recent commentary on the Johannine Epistles, in D. Rensberger, 1 John, 2 John, 3 John (ANTC; Nashville: Abingdon, 1997) 22-24. 
article sketches a new scenario for 1 John which is generated by the same fundamental traditions to which the Fourth Gospel is also a witness. That is, this paper argues for a reading of 1 John, in which foundational convictions are simply restated and commonly held values are reinforced, as a means of strengthening group identity and cohesion in the light of changed circumstances. ${ }^{2}$ This particular horizon is firmly rooted within the first century A.D.

In laying out our argument, we shall deal first with the 'slogans' or 'claims' of an ethical nature, which many scholars claim are the 'boasts' of heretical Christians. ${ }^{3}$ This will lead into the treatment of the theme of $\sin$ in 1 John. In turn, we shall see how this relates to the confessional material in 1 John. This provides us not only with the identification of the boundary between particular groups, but also with a link to the Fourth Gospel.

\section{The Moral Debate}

It is generally agreed that the 'slogans' or 'boasts' of a set of opponents can be isolated within the text of 1 John after the following introductory phrases:

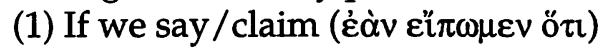

(a) 'We have fellowship with God' (1:6)

(b) 'We have no sin' (1:8)

(c) 'We have not sinned' (1:10)

(2) Whoever says/claims (ó $\lambda \dot{\varepsilon} \gamma \omega v[o ̈ \tau \imath])$

(a) 'I know God' (2:4)

2The approach taken here thus differs from those understandings that interpret $1 \mathrm{John}$ as a response to developing and divergent readings of the Fourth Gospel, as found, for example, in R.E. Brown, The Community of the Beloved Disciple (New York: Paulist Press, 1979) 93-144; and M.C. de Boer, Johannine Perspectives on the Death of Jesus (CBET 17; Kampen: Kok Pharos, 1996).

${ }^{3}$ E.g., R.E. Brown, The Epistles of John (AB 30; New York: Doubleday, 1982) 192-292; J. Painter, The Quest for the Messiah: The History, Literature and Theology of the Johannine Community (Edinburgh: T. \& T. Clark, 1991) 37199; and, in a more nuanced fashion, H.-J. Klauck, Der erste Johannesbrief (EKKNT 23/1; Zurich: Benziger; Neukirchen-Vluyn: Neukirchener Verlag, 1991) $88-98,116-29$. 
(b) 'I abide in God' (2:6)

(c) 'I am in the light' (2:9)

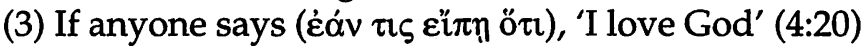

In each case the supposed claim is contradicted by a counterassertion which is related, explicitly or implicitly, to ethical conduct. It is widely assumed that this debating and antithetical style is driven by a polemical purpose, so that the 'claims or the claim/behaviour mismatches which are rejected can be assigned to the schismatics and used to profile and identify them' ${ }^{4}$ So, Raymond Brown argues that these reported statements are claims made by the schismatic 'antichrists' introduced in 2:18-22. He asserts:

In 1.6 the author is fearful that his own adherents in the Johannine Community will be misled by the secessionist interpretation of [the] G[ospel of] John perfectionism whereby the privilege of divine indwelling makes subsequent behavior, even wicked behavior, irrelevant toward salvation. ${ }^{5}$

However, it is far more likely that 1:5-2:11, indeed the whole of 1 John, has a pastoral rather than a polemical outlook, since nowhere are the views of opponents positively stated and refuted. 6 The opening context suggests this. 1 John 1:6-2:2 is hooked into the prologue by the term kolvwvi $\alpha$ which occurs only four times in the letter, all of which are found in 1:3-7. Indeed the only reference to anything outside this intimate

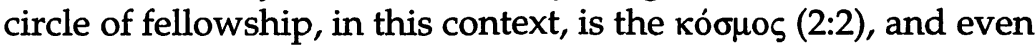
here the world is viewed with the possibility of extension of

4J. Lieu, The Theology of the Johannine Epistles (NT Theology; Cambridge: Cambridge University Press, 1991) 13-14.

${ }^{5}$ Brown, Epistles, 241.

6This point is made, with respect to the confessional material in 2:22 and 4:2-3, by M.C. de Boer, 'Jesus the Baptizer: 1 John 5:5-8 and the Gospel of John', JBL 107 (1988) 87-106, 88. However, his assertion that 5:6 does positively state what the secessionists believe (88-89) is dealt with and rejected below. Note also the neglected article, with many references to 1 John, by K. Berger, 'Die implizierten Gegner: Zur Methode des Erschließens von "Gegnern" in neutestamentlichen Texten', in D. Lührmann and G. Strecker (eds.), Kirche (FS G. Bornkamm; Tübingen: Mohr [Siebeck], 1980) 373-400. 
fellowship to it via divine forgiveness. It seems natural, then, to

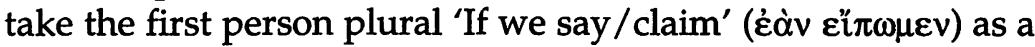
pluralis sociativus, which was widely used in Greek literature as a means by which the writer or speaker 'brings the reader (or hearer) into association with his own action'. 7 The consensus view on the 'slogans' may thus be questioned. 8

Judith Lieu has championed this new approach. She argues:

However serious the schism, the polemic against specific views and claims of opponents does not control the letter or its thought. The so-called 'moral debate' is not explicitly related to the schismatics and so should not be interpreted purely as a reaction against them. ${ }^{9}$

She prefers to describe this passage as 'a self-interrogation'.10 Thus, as she describes it, the author and community together

deliberate the authenticity of their own religious claims and how such claims might be proved invalid... This might, of course, be not genuine debate but rhetorical persuasiveness; perhaps the author seeks to convince his readers by inviting them into a process of deliberation whose conclusions are as

${ }^{7} \mathrm{BDF}$ \$280. The first person plurals in 1:1-5 perform a different function as an authority device, in distinction to those addressed by the second person plurals.

${ }^{8}$ Already in J. Michl, Die katholischen Briefe (RNT 8; Regensburg: Pustet, 1968) 208-209; H. Thyen, 'Johannesbriefe', TRE 17 (Berlin: De Gruyter, 1988) 186-200, 194; G. Strecker, The Johannine Letters (Hermeneia; Minneapolis: Fortress, 1995) 28-29, 61; U. Schnelle, Antidocetic Christology in the Gospel of John: An Investigation of the Place of the Fourth Gospel in the Johannine School (Minneapolis: Fortress, 1992) 61-62; and R.B. Edwards, The Johannine Epistles (NTG: Sheffield: Sheffield Academic Press, 1996) 58$59,67$.

${ }^{9}$ Lieu, Theology, 15-16. See the fuller argument in eadem, "'Authority to become children of God": A Study of 1 John', NovT 33 (1981) 210-28, 22124.

10J. Lieu, The Second and Third Epistles of John (SNTW; Edinburgh: T. \& T. Clark, 1986) 90. 
inevitable as they are implicit in the starting point he has chosen. 11

Similarly, Dietmar Neufeld advances the proposition that John has deliberately set up a series of antithetical statements that

function as rhetorical devices by which he engages the audience to consider carefully what he has to say... Our speech act analysis shows that these slogans may be taken as hypothetical acts of speech that make plain the attitudes and beliefs of the author... He deliberately formulated them as antithetical slogans to show the readers a type of speech which cannot be uttered in sincerity unless they are also willing to accept the full consequences. In this way the author was able not only to present his views about God, light, darkness, love, and sin but also to persuade his readers to accept them. Thus, it could be said that the slogans enabled the author to make the world rather than simply mirror it. They enabled him to bring about states of affairs rather than simply report on them and correct them. ${ }^{12}$

In other words, there is no need to see these statements in 1 John as anything more than rhetorical devices, that reinforce commonly-held beliefs and values, and promote his stated aim 'that you also may have fellowship with us' (1:3). They do not represent views held by real or imagined interlocutors or opponents; such persons are simply not required in order to make good sense of 1:5-2:11, and should fall victim to Ockham's Razor: entia non sunt multiplicanda praeter necessitatem.

This proposal can be amply demonstrated from a survey of the Thesaurus Linguae Graecae. From it, one pertinent facts emerges: the combination of źóv with $\varepsilon i \hbar \pi \omega \mu \varepsilon v$ is quite rare in extant Greek literature, and the largest number of occurrences of this particular collocation is found in the

\footnotetext{
${ }^{11}$ Lieu, Theology, 26. Painter notes the possibility, only to reject it, that the opponents could be a 'literary sounding board against which the author could express his own views' (Quest, 373).

${ }^{12} \mathrm{D}$. Neufeld, Reconceiving Texts as Speech Acts: An Analysis of 1 John (BIS 7; Leiden: E.J. Brill, 1994) 89, 94-95.
} 
Commentaria in Aristotelem Graeca. ${ }^{13}$ An example is that of Ammonius (the pagan fifth- century head of the Platonic school in Alexandria), in whose writing we find a parallel with 1 John 1:6 which is quite striking:

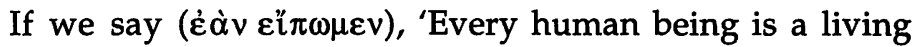
creature,' we speak the truth ( $\dot{\alpha} \lambda \eta \varepsilon v \dot{0} \mu \varepsilon v)$; conversely however, if we say (غ่àv...eï $\pi \omega \mu \varepsilon v)$ ), 'Every living creature is a human being,' we lie ( $\psi \varepsilon v \delta o ́ \mu \varepsilon \theta \alpha) .{ }^{14}$

In other Alexandrian neoplatonist philosophers we see similar examples, such as these:

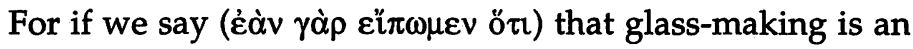
art concerning glass, the definition is complete. 15

But if we say (غ่àv $\delta \dot{\varepsilon} \varepsilon i ̈ \pi \omega \mu \varepsilon v$ ) that the ability to laugh is

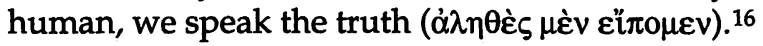

These examples, drawn from lectures, serve to advance the author's argument, and occur in non-polemical contexts. ${ }^{17}$ The same function can also be demonstrated for the introductory phrase ò $\lambda \dot{\gamma} \gamma \omega v$.

13Published 1882-1907 (under various editors) by G. Reimer in Berlin. Henceforth abbreviated $C A G$, and referred to by author, volume number, page number and line number. The English translation is my own.

${ }_{14}$ CAG IV/3, 44.19-22; similarly, Elias, CAG XVIII/1, 7.6-11. Note also Ammonius, CAG IV/4, 72.17 .

15David, CAG XVIII/2, 20.11-13; see also idem, 12.7-9, 19.30-32.

16Philoponus, CAG XIII/3, 246.26-27; similarly idem, 170.23-24. Further examples can be found in Alexander Aphrodisiensis, CAG II/2, 529.2-5; and Themistius CAG XXIII/3, 19.18-19. Note also the grammarian, Herodian: "Therefore, if we say ( vowel, three vowels shall be found in one syllable in $\dot{\rho} \varepsilon \hat{\mu} \mu \alpha$ or $\dot{\rho} 0 \hat{v} \varsigma$, which is impossible' (in A. Lentz, Herodiani Technici Reliquiae 2.1 [Leipzig: Teubner, 1868] 402.4-6; see also ibid., 2.2 [1870] 688.17-23).

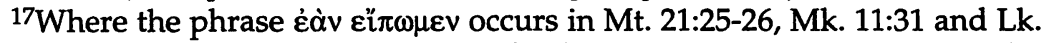
20:5-6, the polemical setting is made clear by the narrative context. The absence of such precise indicators in $1 \mathrm{Jn}$. 1:5-2:11 tells against interpreting it polemically. The antichrists of 2:18ff. are defined by what they deny christologically, and the author has no problem in referring directly to

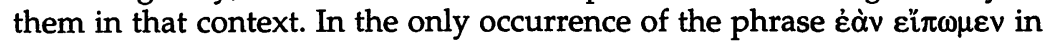
the LXX (4 Kgdms 7:4), the context makes it clear that it is a matter of selfinterrogation among the lepers outside the beseiged city of Samaria. 
For [Protagoras] said that whatever anyone says is true. For the one who says ( $\dot{o} \gamma \dot{\alpha} \rho \lambda \dot{\varepsilon} \gamma \omega v$ ö $\tau$ ) honey is sweet is speaking the truth (for to some it is sweet), and the one who says (o $\lambda \dot{\varepsilon} \gamma \omega v$ ) it is bitter is speaking the truth, for to those who are jaundiced it is bitter. 18

For the one who says ( $\dot{o} \gamma \grave{\alpha} \rho \lambda \dot{\varepsilon} \gamma \omega v$ ) that a certain number is not even says nothing other than that it is odd; and the one who says (ó $\lambda \dot{\varepsilon} \gamma \omega v)$ that a file is not straight says nothing other than that it is crooked. ${ }^{19}$

An example from Philo is instructive. We may note the similarity in form with the simple statements of both 1 John 2:4

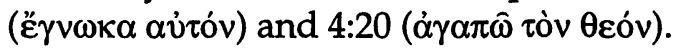

The other half [to that half of the didrachmon which is paid as a ransom for the soul] we are to leave to the unfree and slavish kind of which he is a member who says, 'I have

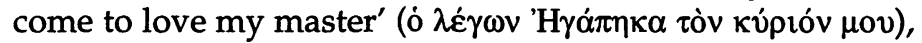
that is, the mind which rules within me. ${ }^{20}$

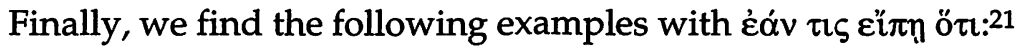

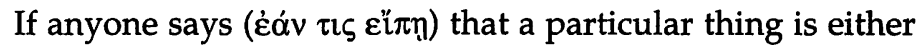
white or black, he perhaps tells a lie; for it is possible for something to be neither black nor white, but grey.22

As in the case of conclusions reached without the use of

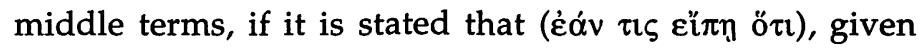

\footnotetext{
${ }^{18}$ Ammonius, CAG IV/4, 66.27-67.2 (cf. Plato, Theaet. 170c ff.); see also Ammonius, CAG IV/5, 93.28-30, 187.30, 208.9, 219.25.

${ }^{19}$ Philoponus, CAG XIII/3, 69. See also idem, XIII/1, 45.16-20, and passim. Further examples can be found in Alexander Aphrodisiensis, CAG I, 372.2-7, 650.20-37; II/1, 404.27-29; II/2, 178.27 and passim; Themistius, CAG XXIII/3, 130.33-34, 131.21-30; David, CAG XVIII/2, 28.3-6; Plato, Charmides, 161d; and Aristotle, Metaphysics, 1011ab, 1047a, 1062a, 1090a.

20Philo, Heres 186; cf. Leg. All. 3.198; also Leg. All. 1.49. Note that 2 Jn. 11

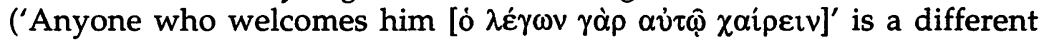
case, as the pronoun is specified within the context.

${ }^{21}$ Other New Testament uses of this phrase contain an additional $\dot{v} \mu \hat{\imath} v$ which specifies the statement or question (Mt. 21:3; 24:23; Mk. 11:3; 13:21; 1 Cor. 10:28).

22Olympiodorus, CAG XII/1, 44.19.
} 
certain conditions, such and such must follow, one is entitled to ask 'Why?'23

All these examples, using the same introductory formulae found in $1 \mathrm{John}$, introduce matters to do with philosophy, logic, geometry, mathematics, grammar and piety, in the service of advancing arguments within a shared worldview. Furthermore, they can all be found in Plato, Aristotle, and their interpreters in the various philosophical schools that were established in the Hellenistic and early Byzantine periods. In these schools the teachings and traditions that gave rise to and constituted these communities were maintained, developed and passed on. For those that posit the existence of a 'Johannine School', established by a founding theologian, the parallels are intriguing. However, it is not necessary to argue the merits of this proposal. All that need be pointed out is that the statements we have been examining in 1 John fit very well with that form of discussion which occurs within certain communities that debate and transmit the traditions which define those communities. The consensus view that understands these statements in 1 John as the 'slogans' of an heretical splinter group may therefore be weighed in the scales of this evidence and found wanting. It is time to let the statements in 1 John $1: 6,8,10 ; 2: 4,6,9$; and 4:20 make there own independent and positive contribution to the argument of 1 John.

\section{Sin in 1 John}

So why does John choose to speak about sin and to speak about sin in the way that he does? The clue is found in the way in which the imagery of light and darkness, introduced in 1:5-7, is taken up and applied to the issue of whether one loves one's

${ }^{23}$ Aristotle, Posterior Analytics, 91b. See also idem, Topica, 126a; Plato, Fifth Epistle, 322d; Philo, Sac. 70; Alexander Aphrodisiensis, CAG I, 349.10, 372.7; II/1, 364.3; II/2, 482.13-14; David, CAG XVIII/2, 112.14-16; Themistius, CAG XXIII/3, 6.26-27; Philoponus, CAG XIII/1, 45.16-20; $\mathrm{XIII} / 3$, 409.12-13; Ammonius, CAG IV/3, 74; IV/4, 34.16-18; Herodian, in Lentz, Herodiani, 2.2, 633.6-8. 
fellow Christian or not (2:9-11). John is concerned to underline what is appropriate behaviour within the community. The image of light and darkness, the concept of truth and falsehood, and the experience of forgiveness and loving one another within the circle of the fellowship of believers, all combine to strengthen the sense of community, and to define its limits.

The theological statement of 1:5, that God is light and in him is no darkness at all, 24 is developed in terms of the word 'sin' ( $\dot{\alpha} \mu \alpha \rho \tau i \alpha)$ in 1:6-2:2. The term 'sin' is not defined in this section. Rather, the emphasis falls on the benefits of walking in the light, namely, that we are cleansed from sins by the blood of Jesus and thereby continue in fellowship with other Christians (1:7). The author is careful to argue that the circle described by light is not a circle of sinless perfection (1:8-10). Christians remain Christians and remain in fellowship with each other precisely because they have an atonement (i $\lambda \alpha \sigma \mu$ ós) for sins (2:2). The cross is at the centre of the circle, and paradoxically believers remain in the light as God is in the light only in so far as they remain under the shadow of the cross. The focus of this section is on individual and personal responsibility to maintain a life in which sins, here left undefined, are confessed and cleansed, so that fellowship with God and one another is unhindered and in the open. In this environment life within the community flourishes.

In the next section (2:3-11), John leaves the concept of 'sin' behind, and introduces the motif of 'commandment'

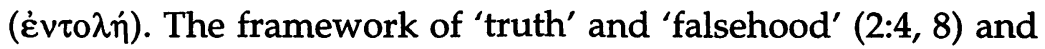
the metaphor of 'walking' (2:6) are carried over, thereby forming a bridge between the two sections. The author's use of 'commandment' terminology enables him to specify a particular sin. The only commandment that is specified as such in 1 John is found in 3:23. It is, in fact, a dual command: 'And this is [God's] commandment, that we should believe in the name of his Son Jesus Christ and love one another, just as he has commanded us' ( $c f .4: 21$ ). The context in 2:3-11 shows us that the second half of the dual commandment is in mind, and

${ }^{24}$ This might be a summary reflection on several passages in the Old Testament, notably Is. 2:5; 10:17; 60:18-20; Ps. 27:1; 104:2. 
this is first signalled by the reference to a 'new' commandment (2:7-8, a clear allusion to John 13:34: 'I give you a new commandment, that you love one another'); then by a reference to the sin that constitutes the breaking of that commandment ('hating a brother or sister' [2:9]); and finally by the statement of the content of the commandment ('Whoever loves a brother or sister'[2:10]). It is in this context that the theme of light and darkness is reintroduced (forming an inclusio with 1:5), but with a greater emphasis on darkness (preparing for the darker themes about to be mentioned). The inclusio with 1:5 demonstrates that John's treatment of sin remains theocentric. Christological concerns are limited to the example of Jesus (2:6), and his role as 'Paraclete' ( $\pi \alpha \rho \alpha \dot{\kappa} \lambda \eta \tau \circ \varsigma)$ before the Father in relation to his sin-bearing work $(1: 7 ; 2: 1-2)$. At this point John's purpose in promoting true fellowship is served, not by focusing upon the community's confession of faith which he here presupposes, but by emphasising their responsibility to each other to walk within the circle of light where God is light, by keeping Jesus' commandment to love one another.

Having occurred eight times in 1:6-2:2, the $\alpha \mu \alpha \rho \tau$ - word group next appears in an isolated traditional formulation in 2:12 (as it does also in 4:10). It then occurs ten times in 3:4-10 and six times in 5:16-18. We therefore note that twenty-four of the twenty-six occurrences of this word group are found in three passages in 1 John. This indicates that John has dealt with the topic of sin in an ordered fashion, and we should expect that his doctrine of sin should have coherence. So what are we to make of John's teaching on sin in 3:4-10, which appears to contradict flatly his teaching on $\sin$ in 1:6-2:2?

The first thing to note is that the treatment of $\sin$ is related to the issue of not loving one's fellow Christian in 3:10,25 and leads into a consideration of the significance of Cain. The second thing to note is that John provides a careful definition of $\sin$ in 3:4: 'sin is $\dot{\eta} \alpha \dot{\alpha} v$ i $\alpha$ [usually translated 'lawlessness'].' Nearly all attempts to resolve the different treatment of $\sin$ in 1:6-2:2 and 3:4-10 assume that both passages are dealing with the same subject, i.e., how the Christian can be described both

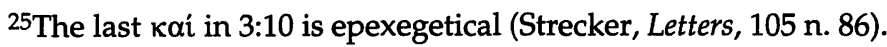


as a sinner and as sinless. However, this assumption fails to take into adequate consideration that 5:16-17 clearly distinguishes two types of sin, and that 3:4-10 occurs after a section dealing with the parousia $(2: 28-3: 3)$, and between sections dealing with the antichrist $(2: 18-23 ; 4: 1-6)$. All this is significant for the definition of $\dot{\eta} \dot{\alpha} \mu \alpha \rho \tau i \alpha$ as $\dot{\eta} \dot{\alpha} v o \mu i \alpha$ in 3:4.

In the LXX $\dot{\alpha} v o \mu i \alpha$ is a synonym for $\dot{\alpha} \mu \alpha \rho \tau i \alpha$ and has the sense of 'lawlessness'. ${ }^{26}$ However, this is unlikely to be the meaning in 3:4 as vómos is not used in $1 \mathrm{John}$, and as we have seen, there is no evidence that John is dealing with libertines. If this were the case then one would expect John to say 'lawlessness is sin', not 'sin is lawlessness'.27 In fact, the articular $\alpha$ voui $\alpha$ indicates much more than merely a tautological definition, rather it represents an intensification of what is meant by ' $\sin ^{2} .28$ This is the import of 3:8a where the

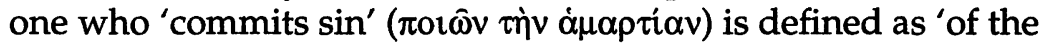

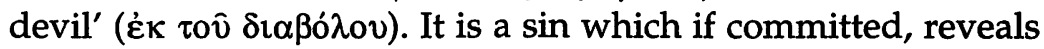
one's origins according to John's dualistic worldview.

The word $\dot{\alpha} v o \mu i \alpha$ is therefore better translated as 'iniquity' or 'rebellion'.29 This nuance seems to be its meaning in eschatological settings. For example, the Testament of Dan 5:4-

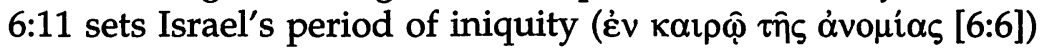
in the context of a final struggle against Satan (6:1-2). ${ }^{30}$

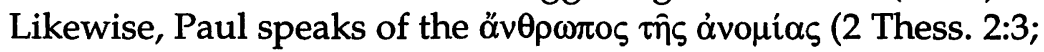

26I.H. Marshall notes, however, 'that the link with the law is weak' (The Epistles of John [NICNT; Grand Rapids: Eerdmans, 1978] 176 n. 3).

27Thus Brown, Epistles, 399.

${ }^{28} \mathrm{BDF}$ gives this definition: 'Predicate nouns as a rule are anarthrous. Nevertheless the article is inserted if the predicate noun is presented as something well known or as that which alone merits the designation (the only thing to be considered)' (\$273.1, with reference to $1 \mathrm{Jn} .3: 4)$.

${ }^{29}$ See W. Gutbrod, 'd่vori $\alpha$ ', TDNT 4, 1085-86; R. Schnackenburg, The Johannine Epistles (Tunbridge Wells: Burns \& Oates, 1992) 171-72; W. Nauck, Die Tradition und der Charakter des ersten Johannesbriefes (WUNT 3; Tübingen: Mohr [Siebeck] 1957) 16 n. 1; Klauck, Johannesbrief, 147-48, 186; Strecker, Letters, 94; Brown, Epistles, 399-400; F. Manns, "Le Péché, c'est Bélial": 1 Jn 3:4 à la lumière du Judaïsme', RevScRel 62 (1988) 1-9; and Lieu, Theology, 52, 61-62.

30In 2 Sa. 22:5 and Ps. 17:5, óvouí $\alpha$ translates בליעל, which in Qumran and the New Testament are a technical name for the devil (Belial/Beliar); note

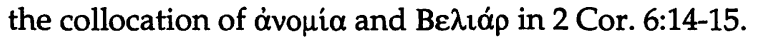


cf. o óvouos [2:8]) in the context of final rebellion against God. We may also note this sense of $\alpha$ vo $\mu i \alpha$ in the following texts: Matthew 24:9-13; the Freer manuscript of the longer ending of Mark; Epistle of Barnabas 4:9 (cf. 15:5; 18:2); Didache 16:3-4; Sibylline Oracles 2:252-62; Martyrdom of Isaiah 2:4, 4:2; and the Apocalypse of Elijah 3 and 5.31 The background to this nuance is found in the LXX, in those contexts which describe the abandonment of distinctive Jewish identity, and give such apostasy an eschatological colouring, such as Theodotion's translation of Daniel 11:29-35, and especially Psalms of Solomon 17:11-32 in which ó ởvouos (17:11; Pompey?) invades the land and causes many Jews to follow Gentile practices $(17: 14-15 ;=\alpha$ ó $\mu \omega v$ [17:18]). The whole passage is full of eschatological imagery, and culminates in the victory of the Lord Messiah (17:32; $c f .17: 21)$.

In summary, these examples understand óvoui $\alpha$ not so much in terms of the 'law' (vó $\mu \circ \varsigma$ ) but in terms of ultimate hostility to God's plan revealed at the end-times. The overall eschatological context in which 1 John 3:4-10 is set, with the mention of the arrival of the antichrist signalling the 'last hour' (2:18), indicates that $\dot{\eta} \alpha{ }^{\prime}{ }^{\prime} \mu \dot{i}^{\alpha}$ in 3:4 functions to define sin in this passage as ultimate rebellion. Therefore, we agree with de la Potterie who argues:

In the dualistic and eschatological context of this passage, [the sin] can hardly be anything but the typical sin of the 'Antichrists', who reject Christ, the Son of God (2.22-23). It is the sin which the Fourth Gospel has described as the sin of the world: that of not believing in Jesus (John 16.11). ${ }^{32}$

This particular definition of $\dot{\alpha} \mu \alpha \rho \tau i \alpha$ is important for understanding the use of $\alpha \mu \alpha \rho \tau-$ throughout 3:4-10 (except for $3: 5$, which is a traditional formulation and contains the only plural form of the noun in the passage). The whole passage is

31The Apocalypse of Elijah, which begins with a quotation from 1 Jn. 2:15 (1:2), mentions 'the son of lawlessness' as the figure who opposes Christ $(3: 1-13 ; 5: 10)$.

32I. de la Potterie, 'Sin is Iniquity (1 Jn. 3:4)', in I. de la Potterie and S. Lyonnet, The Christian Lives by the Spirit (New York: Alba House, 1971) 3755, 50 (emphasis his). 
set within a series of antithetical statements that deal with origins and reveal the identity of those who are 'born of God' or are 'of God' $(2: 29 ; 3: 9-10)$, and those who are 'of the devil' $(3: 8,10)$. When the concept of sin is set within this 'given' framework dealing with origins, it is not surprising, therefore, that it is worked out in ultimate terms of which 'side' one belongs to. In the context of 3:4-10, we are thus dealing with issues to do with who is 'inside' and who is 'outside' the community.

This at once cuts the Gordian knot in which countless commentators have become hopelessly entangled, in trying to resolve the formal contradiction between 1:8, 10 and 3:6, 9 and to explain John's apparent espousal of sinless perfection. If we take John's redefinition of sin in 3:4 seriously and note the eschatological context of 3:4-10, then the resolution is both simple and clear. In 1:6-2:2 John deals with sins that spoil fellowship with God and hinder fellowship within the Christian community. For such sins there is forgiveness through Christ's atoning blood. In 3:4-10 John deals with the sin that destroys fellowship with God, which rejects the atonement that the sinless one provides (3:5), and severs fellowship with the Christian community: namely, apostasy or ultimate rebellion against God. What else could it be that the devil has done 'from the beginning' (3:8)? We therefore translate 3:9 as: 'Those who are born of God do not apostasize, because God's offspring $(\sigma \pi \varepsilon \dot{\rho} \rho \alpha)$ remain in him, indeed they cannot apostasize, because they have been born of God.' 3:9 thus restates in even stronger terms the thought of 3:6: 'No-one who lives in him apostasizes.'

Interpreting 3:4-10 in terms of what distinguishes 'insiders' and those who are now 'outsiders' also makes good sense of the language of 'righteousness' and the introduction of the implicit contrast between the brothers Cain and Abel. Just as ' $\sin ^{\prime}$ ' is particularised in this section, so also is 'righteousness' particularised. It is obedience to the command to love one another, which they have heard 'from the beginning' (3:10-11, 23). The introduction of Cain in 3:12 is carefully prepared for as early as 3:7, where the use of dikalos anticipates the implied 
reference to Abel whose works are $\delta$ í $\alpha \boldsymbol{\alpha} \alpha .{ }^{33}$ The Cain/Abel motif provides a graphic template for developing 3:4-10 more explicitly in terms of loving fellow Christians (3:15). Thus the theme of apostasy is developed in terms of conduct rather than analysed in terms of confession at this point. How one behaves is just as vital as what one believes in determining one's standing with God and fixing the boundaries of the community (3:15-17).34 We conclude that the nature of the sin dealt with in this context is such that it defines the limits of the community as surely as it defines the difference between being the children of God and the children of the devil (3:10), and the difference between life and death (3:14).

Understanding sin as apostasy in 3:4-10 also makes good sense of the discussion of two distinct kinds of $\sin$ in 5:1617: 'unto death' and 'not unto death'. It is not to be thought that the phrase 'all wrongdoing ( $\left.\alpha \delta \delta^{\prime} i \alpha\right)$ is $\sin ^{\prime}$ (5:17), provides the definition of $\sin$ in this context, for unlike 3:4, $\alpha \mu \alpha \rho \tau i \alpha$ is anarthrous and is not the head term, and $\dot{\alpha} \delta \mathrm{r} i \alpha$ is qualified by the generalising 'all' $(\pi \hat{\alpha} \sigma \alpha){ }^{35}$ Of much greater significance is the fact that both types of sin are defined in relation to 'death', (i.e., 'death' and 'not death'), indicating the particular and ultimate nature of the sin 'unto death'. The 'sin unto death' is apostasy. This looks back to the discussion in 3:4-10. It is a sin which, if committed, leads to spiritual and eternal death. The 'sin not unto death' is any other sin for which there is atonement and therefore 'life' after such sin, and this refers to the discussion on $\sin$ in 1:6-2:2.36

Our analysis of 5:16-17 and John's treatment of sin is confirmed by $5: 18$, which returns to analysing sin in terms of

33J.M. Lieu, 'What was from the Beginning: Scripture and Tradition in the Johannine Epistles', NTS 39 (1993) 458-77, 467-72.

${ }^{34}$ Note the following statements, elsewhere in $1 \mathrm{John}$, set in terms of revealing one's origins. Thus the one who loves a fellow Christian is 'born of God' (4:7), as surely as the one who does not do what is right is 'not of God' (3:10); and the one who believes that 'Jesus is the Christ/Messiah is born of God' (5:1), whereas the one who commits apostasy is 'of the devil' (3:8).

35Thus Klauck, Johannesbrief, 330.

${ }^{36}$ This approach to sin in 1 John has a pedigree stretching back as far as Tertullian (De pudicitia 19.10-28). 
origins, and which contains an almost exact repetition of the thought of 3:9. Thus, we may translate 5:18 in this way: 'We know that those who are born of God do not apostasize, but the one who was born of God [Jesus] keeps them, and the evil one does not harm them.' This makes good sense in a context in which John concludes his letter in a forceful and strongly dualistic fashion. The final mention of idols in 5:21 draws on the biblical rhetoric condemning Israel's rebellion and apostasy.

We have argued that the treatment of $\sin$ in 1 John is coherent and is about sin that can be dealt with within the community, and the sin which cannot be dealt with because it puts one outside the community. We are most definitely not dealing with issues of orthodox and heretical perfectionism or alternative Christian understandings of the nature of sin. We are dealing with a set of 'givens' about Christian existence which has a particular focus summarised by the dual command given in 3:23. In that text the matter of conduct is clearly related to and derived from the community's confessional beliefs. We shall argue that, just as there is no need to create a deviant group that is competing for the moral high ground of Christian ethics, so there is no need to create an alternative heretical christological foil that makes sense of the confessional material in 1 John (especially 2:22; 4:2-3; and 5:6).

\section{The Christological Debate}

We shall take the rather innovative step of letting the very simple confessional statement in 2:22 interpret the more obscure statements in 4:2-3 and 5:6. 2:22 reads: 'Who is the liar but the one who denies that Jesus is the Christ.' Hitherto virtually all scholars have argued that 2:22 cannot be understood in its context unless information gleaned from 4:2 and 5:6 be supplied. The result of this procedure usually imports into 2:22 the idea that some have separated the incarnate Jesus from the heavenly Christ. The orthodox reply is understood to say that what God has joined together, Cerinthus or any other heretic must not put asunder.

However, this is not the only way to construe 2:22. What prevents us from concluding that the antichrists deny 


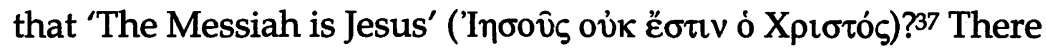
are three instances outside the Johannine corpus that have the same grammatical form as this statement, i.e., an articular

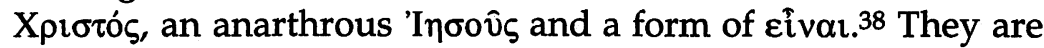
Acts 18:5, 18:28 and 5:42 (in which eivou is understood), the first two instances of which the NRSV and REB translate 'that the Messiah was/is Jesus'. The articular Xpiotós in these constructions indicates that what is being addressed concerns the identity of the Messiah. At issue is not the question 'Who is Jesus?' but 'Who is the Messiah?', and that is a peculiarly Jewish question.

Objections against this line of enquiry involve the claim that such issues had been settled by the time 1 John was written and that, in any case, the context clearly speaks about those who had once been part of the Christian community and had now left (2:19), so how could the antichrists be Jews? The answer is disarmingly straightforward. Jews who had become Christians had apostasised and returned to traditional forms of Judaism by repudiating their belief that the Messiah is Jesus. Justin Martyr tells us that Bar Kochba ordered that Christians alone be cruelly punished unless they would deny Jesus the

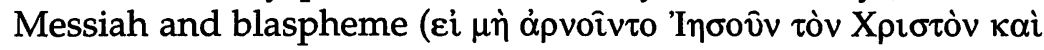
$\beta \lambda \alpha \sigma \phi \eta \mu o i \varepsilon v$ [Apol. I.31]). Furthermore, Justin writes of those Jews who

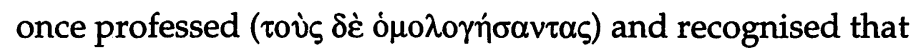
this is the Christ ( cause or other passed over into life under the Law, denying

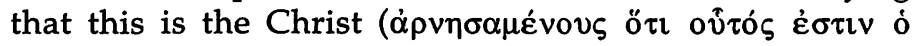

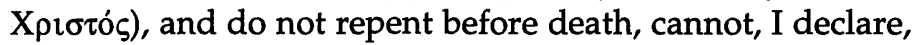
in any wise be saved. ${ }^{39}$

37The ovk is pleonastic at this point.

${ }^{38}$ The same construction is also found in Jn. 20:31; 1 Jn. 5:1; and (with o

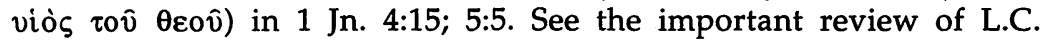
McGaughy, Towards a Descriptive Analysis of EINAI as a Linking Verb in New Testament Greek (SBLDS 6; Missoula: Scholars Press, 1972) by E.V.N. Goetchius in JBL 95 (1976) 147-49.

${ }^{39}$ Dial. 47.4. Translation taken from A.L. Williams, Justin Martyr: The Dialogue with Trypho (London: SPCK; New York/Toronto: MacMillan, 1930). 
Justin's Greek almost parallels 1 John 2:22 word for word at a point which provides a substantial parallel for the scenario we are proposing for 1 John. 40 We can only speculate about what caused a group of Johannine Christians to revert to Judaism. However, the emphasis on denying, and remaining in, the Father and the Son (2:22-24) may indicate that a move away from traditional messianic categories towards the (higher) Father/Son christology of the Fourth Gospel was a step too far for some. But if we take $2: 22$ as a reaffirmation of the community's fundamental confession ( $c f$. Jn. 20:31), how does 4:2-3 fit within this framework?

The whole weight of the docetic-cum-gnostic case in 1 John rests on the modifying phrase 'has come in the flesh' (ív $\sigma \alpha \rho \kappa i ̀ ~ \varepsilon ̇ \eta \eta \lambda v \theta o ́ \tau \alpha, 4: 2)$. It is significant for our discussion to note that in other contexts this phrase means no more than 'enter the world' or 'belong to the realm of space and time'. Indeed, the Long Recension of Ignatius' Letter to the Church at Smyrna rephrases 1 John 4:2 in this way: 'Unless he believes that Christ

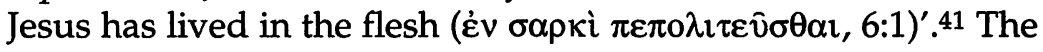
choice of this verb emphasises the fact of Jesus' existence within the world of history rather than emphasising the mode of his incarnation. This is brought out clearly in the Epistle of Barnabas, which was written against a background of bitter antagonism with Judaism, and which has no christological axe to grind other than to assert the messiahship of Jesus. Thus we read in Barnabas 5:10-11:

For if [Jesus] had not come in the flesh ( $\varepsilon \dot{i} \gamma \hat{\alpha} \rho \mu \grave{\eta} \hat{\eta} \lambda \theta \varepsilon v \dot{\varepsilon} v$

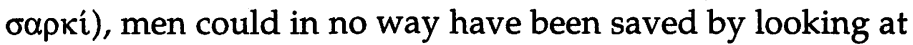
him. For when they look at merely the sun they are not able to gaze at its rays, even though it is the work of his hands and will eventually cease to exist. Therefore the Son of God

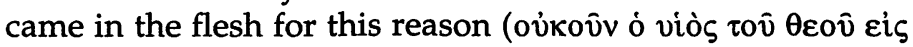

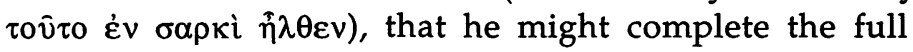
measure of the sins of those who persecuted his prophets to death.

40We have found no reference to this text in the literature on 1 John. ${ }^{41}$ Again there is no mention of this text in the literature on 1 John. 


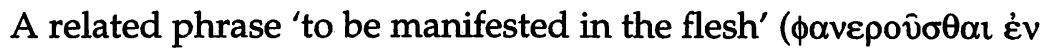
$\sigma \alpha \rho \kappa i)$ also occurs several times in the Epistle of Barnabas, once

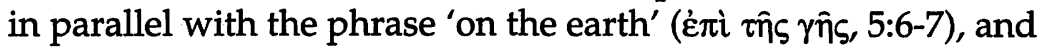
twice with specific reference to Jesus' role as Messiah (6:7-9; 12:10). What is both remarkable and curious about these texts is that no commentary on the Johannine Epistles refers to them in the context of 1 John 4:2.42

However, adducing this background material helps us to make sense of 1 John 4:2 as a more specific confession of Jesus as the Messiah.43 The confession contains a twofold christological element. Firstly, it has to do with 'Jesus', which 4:3 makes clear: 'And every spirit that does not confess $\tau \dot{0} v$ 'Inбov̂v', this Jesus just described as Messiah (the article is anaphoric). 44 And secondly, the confession affirms Jesus as 'Messiah come in the flesh'. We translate the confession of 4:2 in this way: 'Jesus, Messiah come in the flesh.' 45

Furthermore, the immediate context contains a parallel which shows that 'in the flesh' has taken on the neutral sense of 'in the world'.46 1 John 4:3 mentions the 'antichrist' again and

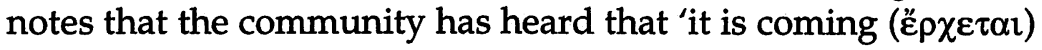
and now is already in the world ( $\dot{\varepsilon} \nu \tau \hat{\varphi}$ кó $\sigma \mu \omega)^{\prime}$. Thus the advent of the antichrist is known through the historical phenomenon of the 'false prophets' who had gone out into the world (4:1). Similarly, the historical advent of the Messiah is known

${ }^{42}$ Klauck makes a passing reference to Barn. 5:10-11 in his full and complete introduction to the Johannine Epistles (Die Johannesbriefe Erträge der Forschung 276 [Darmstadt: Wissenschaftliche Buchgesellschaft, 1991] 19): 'aber das Kommen im Fleisch hat im Barn[abasbriefe] den ganz anderen Sinn einer Akkomodation an das schwache menschliche Fassungsvermögen.' However, he omits all reference to this in his

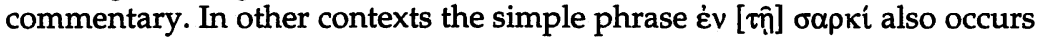

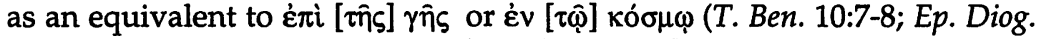
5:8-9; 6:3; 2 Clem. 8:1-2; Historia Alexandri Magni [rec. $\gamma$, lib. 2, 35a.17]).

${ }^{43} \mathrm{~A}$ point made but rejected by R.A. Whitacre, Johannine Polemic: The Role of Tradition and Theology (SBLDS 67; Chico: Scholars Press, 1982) 126.

44On this, see O.A. Piper, '1 John and the Didache of the Primitive Church', JBL 66 (1947) 437-51, 445.

45It may be objected that this requires the article between 'Inoov̂v and

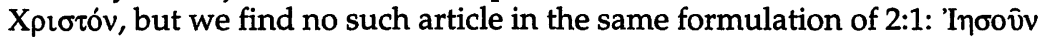

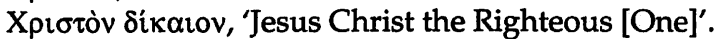

${ }^{46}$ As it also does occasionally in Paul (2 Cor. 10:3; Gal. 2:20; Phil. 1:22, 24). 
through the coming of Jesus. G.W.H. Lampe draws this conclusion from 4:2:

[T] he Spirit of God is recognizable wherever the prophetic spirit acknowledges that Jesus is Messiah come in the flesh, that is to say, that in the concrete person of the historical Jesus the Messiah has truly come... [The teaching of the antichrists] is not the docetic heresy combated by Ignatius, but an attack on the essential Christian faith. 47

We are, in fact very near the thought of Martha's confession in John 11:27: 'I believe that you are the Messiah, the Son of God,

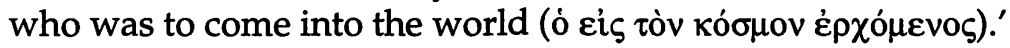

What then are we to make of 5:6: 'This is the one who came by water and blood, Jesus Christ, not with the water only but with the water and the blood'? First, let us note that the language of confession and denial is absent in this passage, as is a reference to 'they' or the 'antichrists', all of which are found in 2:19-22 and 4:1-4. Furthermore, the christological statements in 5:1 and 5:5 are prefaced by 'the one who believes' (o $\pi l \sigma \tau \varepsilon v i \omega v)$, the verb which is used for purposes of affirmation in 1 John rather than polemic. Second, the function of the construction 'not only....but also' is rhetorical, not polemical. The same construction is found at 2:2: 'and he is the atoning sacrifice for our sins, and not only for ours but also for the sins of the whole world.' Are we here to conclude that John is pitching at proto-Calvinists in a debate about the extent of the atonement? Whatever is being affirmed in 5:6 is concerned solely with what the community believes, and not with what others may or may not be asserting about Jesus. ${ }^{48}$ Finally, it is

${ }^{47}$ G.W.H. Lampe, '“Grievous Wolves" (Acts 20:29)', in B. Lindars and S.S. Smalley (eds.), Christ and Spirit in the New Testament (FS C.F.D. Moule; Cambridge: Cambridge University Press, 1973) 253-68, 262. See also J.C. O'Neill, The Puzzle of 1 John: An Examination of Its Origins (London: SPCK, 1966) 46; E. Stegemann, "'Kindlein, hütet euch vor den Götterbildern!" Erwägungen zum Schluß des 1. Johannesbriefes', TZ 41 (1985) 284-94, 294; Thyen, 'Johannesbriefe', 193; G. Bardy, 'Cérinthe', RB 30 (1921) 344-73, 349; Piper, 'Didache', 445; J. Blank, 'Die Irrlehrer des ersten Johannesbriefes', Kairos: Zeitschrift für Religionswissenschaft und Theologie 26 (1984) 166-93, 189-90.

${ }^{48}$ Contra de Boer, Perspectives, 258. 
extremely difficult to see what heretical viewpoint might be in view and how this particular formulation would combat it.

The clue to the purpose of 5:6-8 lies in the function of the three witnesses of the Spirit, the water and the blood in the present experience of the community (note the present tenses in 5:7-8). The three witnesses are in agreement and the agreement concerns the testimony that God has given about his Son concerning eternal life (5:9-12). Together the gift of the Spirit (cf. $3: 24 ; 4: 13)$, the water of baptism, and the cleansing blood of Jesus (which provides forgiveness and is presumably witnessed to by the eucharist) form the identity markers that distinguish the Johannine community from its Jewish milieu; they provide symbols and shared experiences that strengthen their separate identity as believers in Messiah Jesus. These symbols are the sociological analogue of their christological beliefs.

We note here the similar argument that Charles Cosgrove makes with reference to the Fourth Gospel:

[T] he point of the literal eating and drinking in John 6.53ff. lies in the fact that participation in the eucharistic meal represents public identification with the Johannine community as an indispensable condition for 'abiding in Jesus' and thus receiving his Life... It is the Spirit that gives life: the Spirit-Paraclete of the glorified Jesus present in the community and nowhere else.

On the water imagery in John 3, Cosgrove says:

Jesus tells Nicodemus that no one can enter the kingdom without being born 'of water and the Spirit' (v. 5). One would think the Spirit should suffice, which is what Jesus goes on to say in v. 6. But birth by the Spirit, however inexplicable and mysterious, is not a matter simply of the individual heart. It is tied up with 'water', which means entrance into the community through baptism. 49

Thus the one who began his public ministry with the reception of the Spirit and the water of baptism, and ended his public

${ }^{49}$ C.H. Cosgrove, 'The Place Where Jesus Is: Allusions to Baptism and the Eucharist in the Fourth Gospel', NTS 35 (1989) 522-39, 529, 531 (emphasis his). 
ministry with the shedding of his blood on the cross, Jesus the Messiah, is the one who creates a new community and sustains it through the Spirit, the water and the blood. The rhetorical emphasis in 1 John 5:6 on the blood serves to remind the Johannine community that 'the Messiah and him crucified' is what they preach, and which is still a stumbling-block to Jews.

\section{Apostasy and Johannine Christianity}

The teaching about eating and drinking the flesh and blood of Jesus in the Fourth Gospel is followed in 6:60-71 by an explicit reference to apostasy: 'Many of his disciples turned back and no longer followed him' (6:67). This is precisely the backdrop we are painting for 1 John. This is further confirmed by the fact that the closest verbal correspondences that can be found between two passages from the Fourth Gospel and 1 John also concern a context of apostasy in the Fourth Gospel. We refer to the difficult and controversial passage of John 8:31-59.

The parallels between 1 John and John 8:31-59 have been frequently observed. Judith Lieu notes that ' 1 John uses against internal enemies language which in the Gospel is used of those outside, chiefly the Jews' .50 For example, the phrase

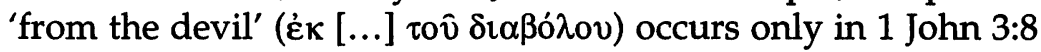

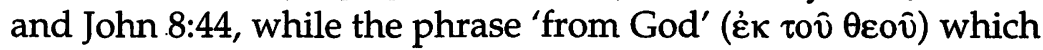
occurs three times in 1 John 3:9-10 is found only in John 7:17, $8: 42$ and 8:47 in the context of disputes with Jews; 'murderer'

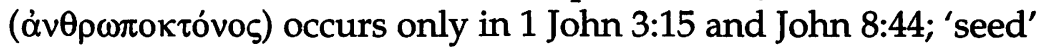
( $\sigma \pi \varepsilon \dot{\rho} \mu \alpha)$ occurs only in 1 John 3:9 and John 7:42, 8:33, and 8:37;

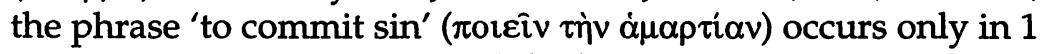
John 3:4, 8, 9 and John 8:34; while the 'false' word group ( $\psi \varepsilon v \sigma-$ / $\psi \varepsilon v \delta-)$ which occurs nine times in 1 John is found only in John

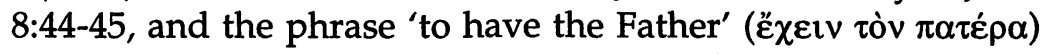
occurs only in 1 John 2:23 and JWherefel, we propose that those against whom such language is used in 1 John are precisely those described in John 8:31 as 'the Jews who

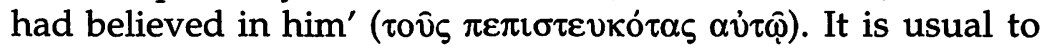
understand the participle in the sense of those who had

${ }^{50}$ Lieu, Theology, 100. 
believed in Jesus and still do, on the basis that 8:30 refers to a group who believe in Jesus. ${ }^{51}$ However, two factors militate against this interpretation. First, in the context of a series of seven dialogues in John 7-8, Mark Stibbe notes that 'there is a sense of closure at the end of John $8.30 .$. A new episode then begins with the narrator's introduction of a different audience [John 8.31]'.52 Second, the subsequent debate assumes that Jesus' interlocutors are not believers. Indeed, they are on the receiving end of the fiercest polemic to be found in the Fourth Gospel. Therefore, it seems better to render the perfect participle by the pluperfect 'those who had believed in Jesus (but do so no longer)' ${ }^{\prime} 3$ Stibbe comes to this conclusion about John 8:31-59:

This is a group of Jews who were followers of Jesus, but who then, under a pressure which is not described by the narrator, start to revert to their former religious beliefs. Instead of holding on to the teaching of Jesus, they now claim that Abrahamic descent is sufficient for membership of the covenant community and, by implication, for salvation... Jesus is not attacking the Jewish people in general. Far from it. He is satirizing apostasy in 8.31-59. He is satirizing those who start on the road to discipleship, but who give up when the going gets tough. 54

${ }^{51 E . g ., ~ J . ~ M c H u g h, ~ " I I n ~ h i m ~ w a s ~ l i f e ": ~ J o h n ' s ~ G o s p e l ~ a n d ~ t h e ~ P a r t i n g ~ o f ~ t h e ~}$ Ways', in J.D.G. Dunn (ed.), Jews and Christians: The Parting of the Ways AD 70 to 135 (WUNT 66: Tübingen: Mohr [Siebeck], 1992) 123-58. He argues that Jn. 8:31-59 is 'an apologetic, even a polemic, directed not against Jews but against Jewish converts to Christianity who were unwilling to accept the full Johannine doctrine about Jesus Christ...[The writer] is asking them whether they wish to be Jews or Christians, convinced that the time is past when one could be both' (143-44). Note also Lieu, 'Beginning', 477. ${ }^{52}$ M.W.G. Stibbe, John's Gospel (NT Readings: London: Routledge, 1994) 112.

53So also K.L. McKay, 'On the Perfect and Other Aspects in New Testament Greek', NovT 23 (1981) 289-329, 312; Thyen, 'Johannesbriefe', 191; Stibbe, Gospel, 123; NRSV; NIV; REB. This requires taking the resulting state as antecedent to the main verb, as in Jn. 11:44: $\dot{o} \tau \varepsilon \theta v \eta \kappa \omega ́ s$ (of Lazarus who had died, but was dead no longer).

54Stibbe, Gospel, 124. 
Stibbe's conclusion provides corroboration of our analysis of 1 John, as it provides a parallel in the Fourth Gospel for exactly the kind of situation that we have proposed for 1 John, precisely at a point where the traditions of the Fourth Gospel and 1 John converge very closely at a verbal level. We have attempted to show that $1 \mathrm{John}$ represents one further example of the gradual and complex separation between synagogue and church, and that the contours of the debate in $1 \mathrm{John}$ are still very much moulded by the conflict with the Jews in the Fourth Gospel.

The objection may be made that if this were the case then one is surprised to find no explicit mention of 'the Jews' nor any Old Testament quotations, as in the Fourth Gospel, in 1 John. ${ }^{5}$ However, in the material in the Fourth Gospel which most resembles the style of internal community discussion in 1 John, namely John 14-16, there is no mention of the term 'Jews', and there is only one Old Testament quotation. 56 Furthermore, the most vivid description of Jewish persecution of Christians is found in John 15:18-16:4 with its warning against 'falling away' (cf. Jn. 6:61) and its talk of being put out of the synagogue and being killed. Yet the language used to describe the Jews is nonspecific. They are simply labelled as 'the world'; the world that 'hates' Christians (cf. Jn. 7:7, 15:18-19, 23-25; 1 Jn. 3:13).

We have seen, therefore, that the background of Jewish Christians returning to Judaism provides a good explanation for the rhetoric of $1 \mathrm{John}$. It also gives an extra twist to the tension in the ethic of love (namely that between brothers only), and gives greater depth to the sense of betrayal which produced the term 'antichrist'. John's aim throughout is a pastoral one-to secure the boundaries of the community against further losses. He achieves it (1) by recalling the community to its foundational confession; (2) by reminding

55Thus D.A. Carson, 'John and the Johannine Epistles', in D.A. Carson and H.G.M. Williamson (eds.), It Is Written: Scripture Citing Scripture (FS Barnabas Lindars, SSF; Cambridge: Cambridge University Press, 1988) 245-64, 256; D. Moody Smith, The Theology of the Gospel of John (NT Theology; Cambridge: Cambridge University Press, 1995) 57-58.

56In fact, the only private discussions between Jesus and his disciples in the Fourth Gospel are found in Jn. 1:37-51; 4:31-38; 6:60-71; and chs. 13-16. 
them of their common experience of the Spirit, of baptism, and of forgiveness through the blood of Jesus; and (3) by urging them to continue to love one another. 